\title{
Analysis of Mariupol Metallurgical Enterprises Influence on Ecological State of Surface Waters
}

\section{Introduction}

The current environmental situation in Ukraine can be described as a critical, formed over a long period due to neglect of the objective laws of development and reproduction of natural resources of Ukraine. There was a structural deformation of the economy of Ukraine, in which priority was granted to the development of raw materials extraction. Just this industry is considered to be the most environmentally dangerous.

The main reasons which led to the threatening state of the environment are as follows:

- outdated equipment and production technology, high energy intensity and material consumption of industrial processes, 2-3 times exceeding the same parameters of developed countries;

- a high concentration of industrial facilities;

- unfavorable structure of industrial production with a high contribution of environmentally hazardous activities;

- the absence of proper environmental protection systems (sewage treatment plants, closed water cycle systems etc.), low level of operation of existing environmental objects;

- lack of adequate legal and economic mechanisms which would encourage the development of environmentally sound technologies and environmental protection systems;

- lack of proper control and monitoring of the environment quality.

The iron and steel industry (including ferrous and nonferrous metallurgy, coking and rolling production, as well as related ancillary facilities and processes) is one of the most polluting industries which emissions from stationary sources of pollution reaches up to $38 \%$ of the total amount of pollutants [1].

* Pryazovskyi State Technical University, Faculty of Metallurgy, Mariupol, Ukraine

** AGH University of Science and Technology, Faculty of Mining Surveying and Environmental Engineering, Krakow, Poland 


\section{Assessment of Running Water and Marine Coastal Zone State}

Currently, since 2004 Mariupol is the city which is characterized by the highest level of air pollution and water bodies from stationary pollution sources on the background of other regions in Ukraine and Europe. The reason for this is the fact that in Mariupol there are situated two largest steel companies of the Donetsk region: Azovstal Iron \& Steel Works and Ilyich Iron and Steel Works (Metinvest holding, System Capital Management).

Azovstal Iron \& Steel Works (Fig. 1) is the only Ukrainian manufacturer of high-quality rolled products with a thickness of 6-200 $\mathrm{mm}$ and width of 1500-3200 mm for shipbuilding, power engineering and special machine production, bridge construction, large diameter pipe manufacturing for arctic main gas and oil pipelines and off-shore structures. The rolled products are subjected to $100 \%$ non-destructive ultrasonic testing. AZOVSTAL IRON \& STEEL WORKS is the only enterprise where continuous production of ultra-high-strength steel X70 and X80 has been improved [2].

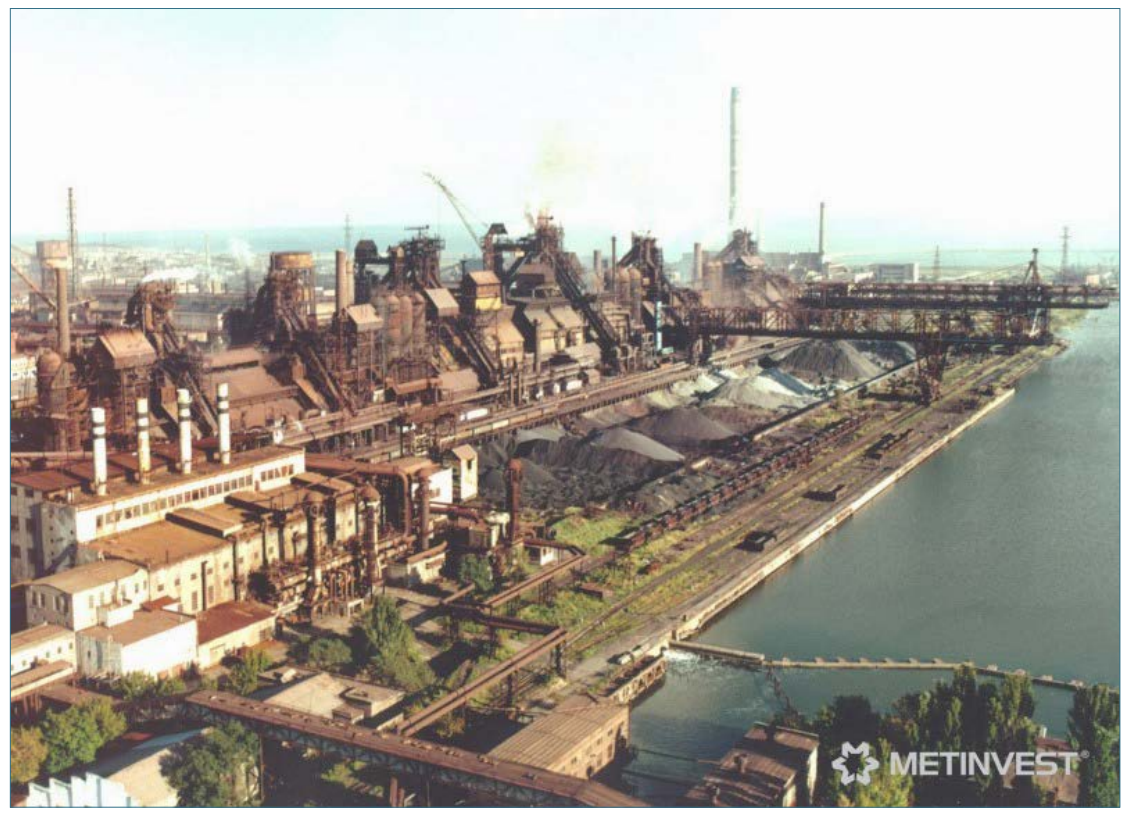

Fig. 1. Azovstal Iron \& Steel Works (Mariupol, Ukraine)

Source: [4]

Ilyich Iron and Steel Works (Fig. 2) specializes in the production of sinter, lime, iron and iron products, steel ingots, cast and rolled slabs, high quality steel sheet and plate for high-duty metal constructions, shipbuilding, oil, gas and water pipes, electrodes and flux-cored wire for modified melts [3]. 


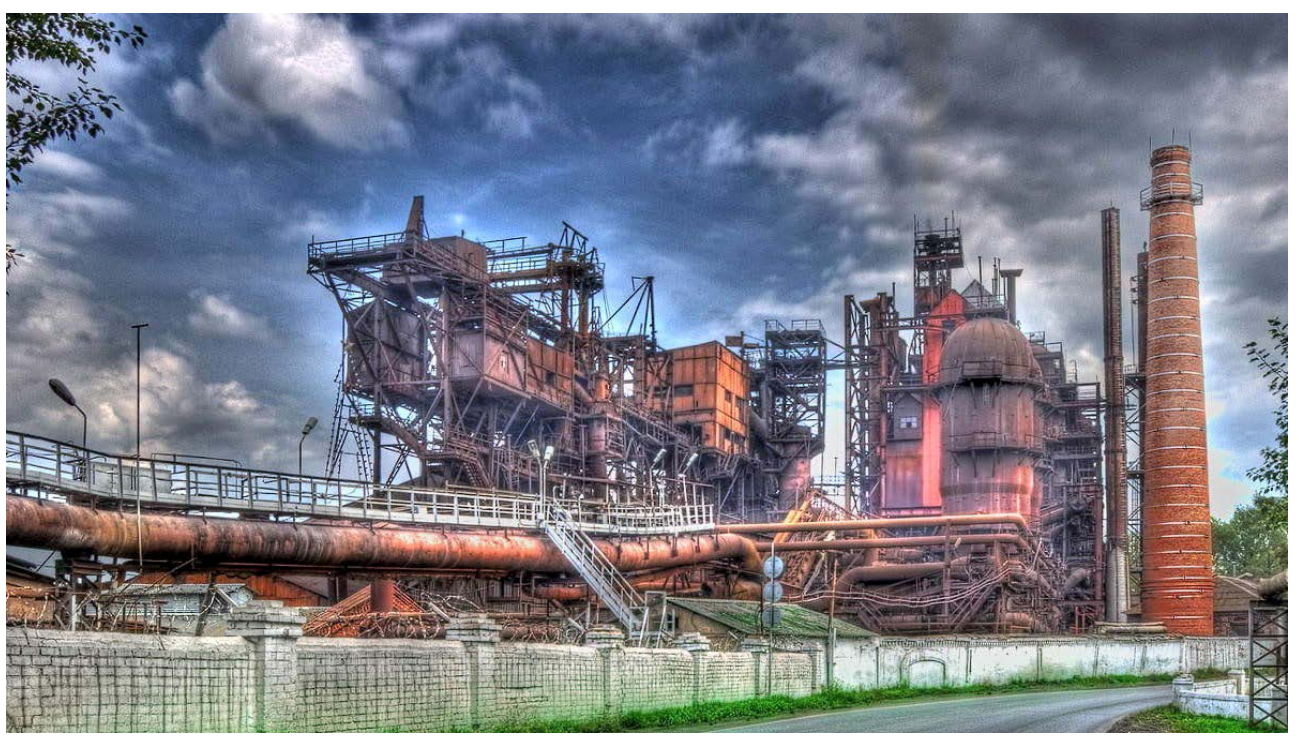

Fig. 2. Ilyich Iron and Steel Works (Mariupol, Ukraine)

Source: [3]

In 1999 enterprises of Mariupol discharged into surface water bodies (the rivers Kalchyk, Kalmius and coastal zone of the Sea of Azov) about $885.0 \mathrm{mln} \mathrm{m}^{3}$ of wastewater (including $403.9 \mathrm{mln} \mathrm{m}^{3}$ of untreated waste water). Among others there are:

- 87.1\% - $770.5 \mathrm{mln} \mathrm{m}^{3}$ (Azovstal Iron \& Steel Works) of which $357.9 \mathrm{mln} \mathrm{m}^{3}$ of untreated waste water;

- 5.1\% - $45.5 \mathrm{mln} \mathrm{m}^{3}$ (Ilyich Iron and Steel Works).

Figure 3 shows the amount of emissions of polluted wastewater in the period from 1999 to 2007 from Azovstal Iron \& Steel Works (a) and Ilyich Iron and Steel Works (b).

The results of the assessment of water pollution level of running waters and the sea coastal zone within Mariupol urban area are presented in Table 1. The assessment was based on the data on the pollutants content in the river Kalmius and the coastal zone of the Sea of Azov, bordering the Mariupol city.

The main sources of pollution of the costal are of the Sea of Azov are the river Kalmius, of municipal wastewater discharges and industrial wastewaters from Azovstal Iron \& Steel Works and Ilyich Iron and Steel Works. At the same time almost half of $160 \mathrm{mln} \mathrm{m}^{3}$ of wastewater are annually discharged into the Sea of Azov by enterprises of Metinvest Holding. Recorded concentrations of polluting substances in the water of the Kalmius river below the discharge of industrial waters from metallurgical plants are given in Table 1. The content of chlorides, sulphates, phenol, petroleum products and nitrates exceed the maximum permissible concentrations (MPC) of harmful substances established by in the national legislation acts. 

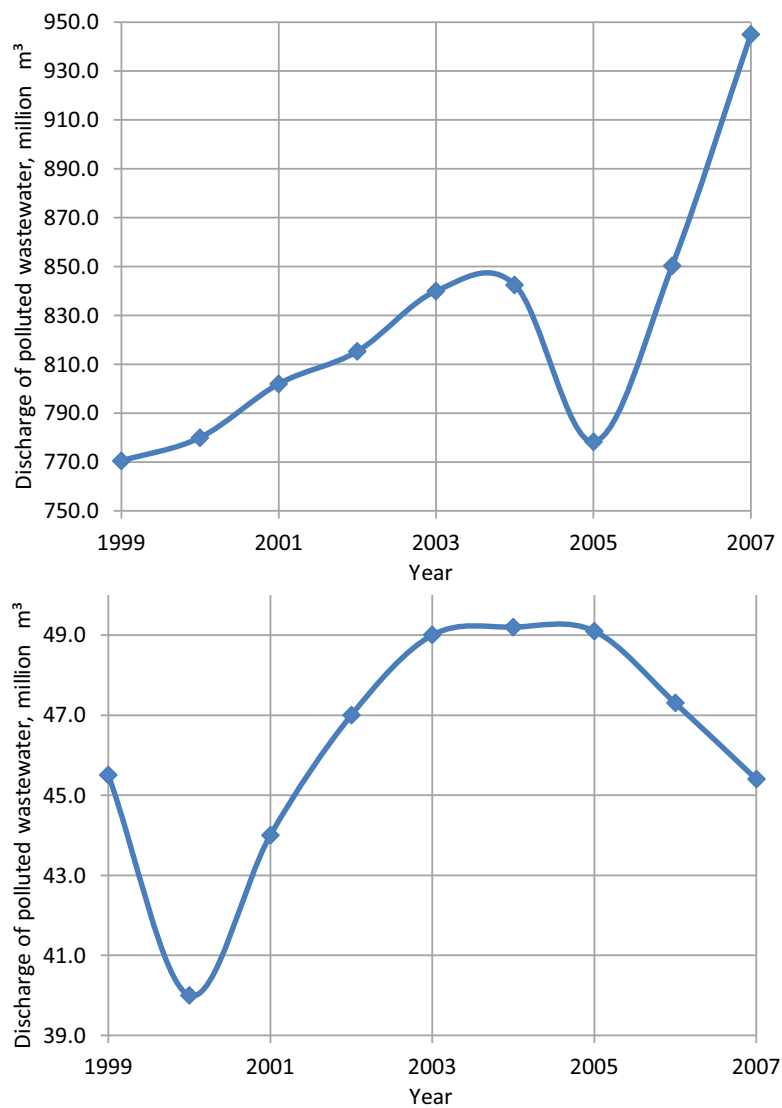

Fig. 3. Amount of polluted wastewater discharge (1999-2007):

a) from Azovstal Iron \& Steel Works; b) from Ilyich Iron and Steel Works

Table 1. Concentrations of pollutants in the Kalmius river below the discharge of industrial wastewaters of Metinvest Holding

\begin{tabular}{||l|c|c||}
\hline \multicolumn{1}{|c|}{ Polluting substances } & $\begin{array}{c}\text { Concentration } \\
{[\mathrm{mg} / \mathrm{L}]}\end{array}$ & $\begin{array}{c}\text { MPC } \\
{[\mathrm{mg} / \mathrm{L}]}\end{array}$ \\
\hline Mineralization & 2975 & 2300 \\
\hline Chlorides & 440 & 356 \\
\hline Sulfates & 987 & 930 \\
\hline Thiocyanates (thiocyanates) & 0.05 & 0.14 \\
\hline Phenol & 0.009 & 0.001 \\
\hline Petroleum products & 0.33 & 0.3 \\
\hline Nitrates & 77 & 45 \\
\hline Copper & 0.02 & 0.03 \\
\hline Zinc & 0.14 & 0.3 \\
\hline Chrome & 0.005 & 0.01 \\
\hline Nickel & 0.02 & 0.03 \\
\hline
\end{tabular}


The most common index for determining the quality of water used in Ukraine is the Water Pollution Index (WPI) [5]. On the stenth of this index it is possible to assess the quality of water and to classify the water according to hydrochemical parameters into seven classes of quality (Tab. 2).

Table 2. Classification of water quality

\begin{tabular}{|c|c|c||}
\hline WPI value & Class & Water quality \\
\hline \hline$\leq 0.25$ & I & very clean water \\
\hline $0.25-0.75$ & II & pure water \\
\hline $0.75-1.25$ & III & moderately contaminated \\
\hline $1.25-1.75$ & IV & dirty \\
\hline $1.75-3.00$ & V & very dirty \\
\hline $3-5$ & VI & extremely dirty \\
\hline$>5$ & VII & \\
\hline
\end{tabular}

On the base of Water Pollution Index value equal to 3-5 the hydrochemical state of the of Kalmius river within Mariupol urban area was classified as very dirty.

The monitoring system of marine pollution of Mariupol Hydrometeorological Observatory covers four stations of the category I (located close to pollution discharge). Stations of the category I are designed to control the state of marine pollution in areas of public recreation areas in wastewater recipients. At ten stations of the category II observations are carried out twice a year with the help of a small fleet of ships. They cover a large area of the Sea of Azov and are not subjected to the direct influence of heavily contaminated wastewater.

The result of the dynamics of sea water quality in the period of 2006-2011 estimated on the base of WPI value is presented in the chart of Figure 4.

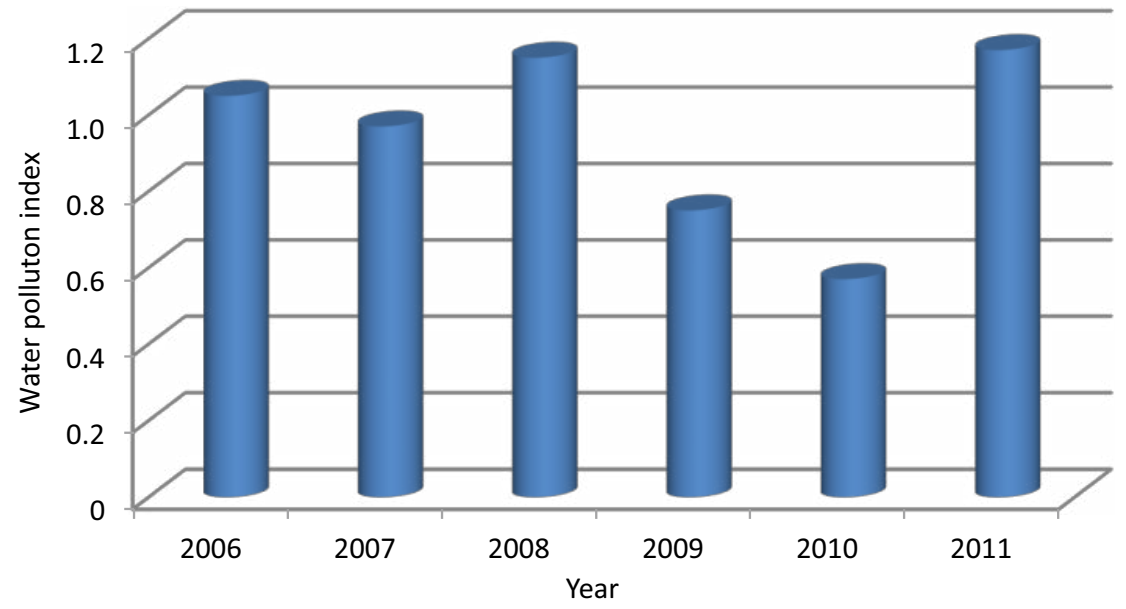

Fig. 4. Dynamics of WPI value for the 6-year period (2006-2011) at the sea monitoring stations of the category I (near Mariupol) 
In regard to the changes of sea Water Quality Index WPI we can state the following dynamics of sea water quality. On stations of the category I in 2011 WPI increased by 0.6 , compared with the previous year, and reached the III level of pollution (moderately polluted), corresponding to WPI value 1, 2, i.e. the level of "pre-crisis" in 2008. In 2009 and 2010 the level of WPI tended to reduce, apparently because of the decline in industrial production and reduction of discharges of improperly treated wastewater into rivers and the sea. In 2011, the trend of water pollution has changed to positive. WPI value growth in 2011 can be explained by the increase of nitrite and ammonia content in sea water. Water-quality class is changed to III and so, sea water quality should be characterized as moderately polluted.

At the stations of the category I in the coastal zone of the Sea of Azov in 2011, compared with the previous year, WPI increased slightly due to nitrite nitrogen and reached the value of 0.4 as in 2007 . The trend of water pollution changes is positive. Water quality class is II, water is characterized as "clean".

An economic crisis and a decline of industrial production in 2009-2010 years, including Mariupol enterprises, had a significant impact on the water environment, which led to a temporary improvement of water quality in the Sea of Azov.

The highest level of pollution is observed in estuaries: the content of nutrients (nitrites, nitrates, phosphates, ammonia nitrogen, silicon) are higher than in other monitoring stations. This is due to the discharge of improperly treated wastewater from industrial enterprises, agricultural complexes and domestic wastewater.

Among the highest sources of negative impacts on the marine environment are pollutants generated by the ports and shipping companies contaminating the water as the result of the transport of potentially dangerous substances: of fertilizers, oil and oil products and other.

Slag dumps and landfills located in the immediate neighborhood to the sea form the next source of dangerous pollution as the result of contaminated water infiltration into the groundwater and surface water, which later fall into the Sea of Azov.

\section{Summary}

Currently Azovstal Iron \& Steel Works and Ilyich Iron and Steel Works introduced measures to improve the ecological state of surface waters and the coastal zone of the Sea of Azov (e.g., construction of recycling fine sludge facilities, introduction of closed water cycle, gas cleaning converters, maintenance and adjustment of biochemical waste water for the treatment of wastewater from coke production etc.). The positive results of these environment protection undertakings should lead to an improvement of ecological situation in the near future. 


\section{References}

[1] Resolution of the Verkhowna Rada of Ukraine on March 5, 1998 №188/98-VR “On the main directions of state policy in the field of environmental protection, natural resource management and environmental security". Bulletin of the Verkhovna Rada of Ukraine, 1998, no. 38-39.

[2] Azovstal Iron \& Steel Works [official website]. [on-line:] http://azovstal.met investholding.com/ua [access: 15.01.2015].

[3] Ilyich Iron and Steel Works [official website]. [on-line:] http://ilyichsteel.met investholding.com/ru [access: 03.02.2015].

[4] Metinvest Holding [official website]. [on-line:] http://www.metinvesthold ing.com/en [access: 30.01.2015].

[5] Gagarina O.V.: Obzor metodov kompleksnoy otsenki kachestva poverkhnostnykh vod. Vestnik Udmurtskogo universiteta. Biologiya. Nauki o Zemle, no. 11, 2005, pp. 45-58 [Гагарина О.В.: Обзор методов комплексной оценки качества поверхностных вод. Вестник Удмуртского университета. Биология. Науки о Земле, № 11, 2005, с. 45-58]. 